\title{
An overview and profile of the ICF's use in Brazil - a decade of history
}

Panorama e perfil da utilização da CIF no Brasil - uma década de história

João A. Ruaro', Marinêz B. Ruaro', Damião E. Souza², Andersom R. Frézz , Ricardo O. Guerra

\begin{abstract}
Background: In 2001the World Health Organization (WHO) adopted a classification system for understanding functioning and human disability: the International Classification of Functioning, Disability and Health (ICF). The ICF's acceptance and use has been facilitated by the development and global consensus process, with increasing evidence about its validity. Objectives: To investigate the overview of the use of the ICF in Brazil, since its conception in 2001 until the year 2011. Method: We conducted an integrative literature review by searching SciELO, Lilacs, PubMed and ISI databases. To be included in the review, the study must have been published as scientific article, editorial or technical note, and had to having the participation of Brazilian researchers or have been developed in Brazil. Results: One hundred and two publications were identified, but only 47 studies were included based in the inclusion criteria. Most of eligible studies were related to neurology $(n=16)$ and orthopaedics $(n=12)$ subdisciplines. The university that most appeared in the publications in national journals was The Universidade de São Paulo (11) and in the international journals was Universidade Federal de Minas Gerais (4). In 2003 there was only one publication; in 2010 and 2011 were 10 and 8, respectively. Conclusions: Although incipient, the use of ICF in the Brazilian scientific community is rising. There is a concentration of studies related to the locomotor system, as well as performed by universities in the southeast area of Brazil.
\end{abstract}

Keywords: international classification of functioning, disability and health; review; database; health status indicators; physical therapy.

\section{Resumo}

Contextualização: Em 2001, a OMS aprovou um sistema de classificação para o entendimento da funcionalidade e da incapacidade humana: a Classificação Internacional de Funcionalidade, Incapacidade e Saúde (CIF). A aceitação e a utilização da CIF vêm sendo facilitadas pelo seu desenvolvimento e processo de consenso global, com crescente evidência sobre a sua validade. Objetivos: Investigar o panorama do uso da CIF no Brasil desde a sua concepção em 2001 até o ano de 2011. Método: Revisão integrativa da literatura com consulta às bases de dados SciELO, Lilacs, PubMed e ISI. Para ser incluído na revisão, o trabalho deveria ter sido publicado na forma de artigo científico, editorial ou nota técnica, além de ter a participação de pesquisadores nacionais ou ter sido desenvolvido no Brasil. Resultados: Foram identificadas 102 publicações; em seguida, a partir dos critérios de seleção, foram analisados 47 estudos, sendo a sua maioria nas áreas de neurologia (16) e ortopedia (12). A instituição de ensino que mais aparece nas publicações em periódicos nacionais é a USP (11) e, em internacionais, é a UFMG (4). Em 2003, houve apenas uma publicação, já em 2010, foram dez e, em 2011, oito. Conclusões: Apesar de incipiente, o uso da CIF na comunidade científica brasileira está em ascensão. Há uma concentração de estudos nas áreas relacionadas ao aparelho locomotor bem como nas instituições da região sudeste.

Palavras-chave: classificação internacional de funcionalidade, incapacidade e saúde; base de dados; revisão; indicadores básicos de saúde; fisioterapia.

Received: 04/13/2012 - Revised: 06/23/2012 - Accepted: 07/19/2012

'Postgraduate Program in Health Sciences, Universidade Federal do Rio Grande do Norte (UFRN), Natal, RN, Brazil

2Instituto Brasileiro de Geografia e Estatística (IBGE/RN), Natal, RN, Brazil

3Physical Therapy Department, Universidade Estadual do Centro-Oeste (Unicentro), Guarapuava, PR, Brazil

${ }^{4}$ Physical Therapy Department, UFRN, Natal, RN, Brazil

Correspondence to: João Afonso Ruaro, Faculdade de Ciências da Saúde - Universidade Federal do Rio Grande do Norte (FACISA/UFRN), Rua Trairí, s/n, CEP 59200-000, Santa Cruz, RN, Brasil, e-mail: joaoruaro@bol.com.br 


\section{Introduction $\because \therefore$.}

One of the missions of the World Health Organization (WHO) consists in the production of health classifications that represent consensual models to be incorporated by the health systems, managers and users, with the aim to use a common language for the description of problems or interventions in health ${ }^{1}$. Thus, in 2001, the WHO approved a classification system for the understanding of functionality and human disability: the International Classification of Functioning, Disability and Health (ICF), an appropriate tool for the identification of structural and environmental conditions and the personal characteristics that affect the functionality. Overall it proposes to provide a unified and standardized language through a framework for the description of health and health-related states, helping communication and the information exchange. This classification is divided into four components: body functions; body structures; activities and participation; and environmental factors ${ }^{2}$.

The ICF provides a standard classification that takes into account the presence and the severity of a health problem, either in the individual or social aspect. This type of classification allows the standardization of language about functionality and, consequently, for the progressive construction of scales that qualify the health-disease-functionality-care phenomenon ${ }^{3}$. Thus, it demonstrates the shift from a disease-based approach to an approach that prioritizes functionality as a component of health, as well as considering the environment as facilitator or barrier for the performance of actions and tasks ${ }^{4}$, since functionality became the central point for evaluation and determination of health conduits ${ }^{5}$.

Within this context, health is seen as a resource for life by emphasizing the social, personal resources and physical capacity. This is the multi-directionality of the ICF model, in which the environmental, social and personal factors are no less important than the presence of the disease in determining function, activity and participation. Therefore, the ICF and its model assume great epidemiological importance, since the social factor is crucial for a population's level of health ${ }^{6}$. In addition, the patients' perspectives are taken into consideration and the work should be directed towards functionality and capacity that the patient desire to have, according to their needs, life options, environmental, social influences and the presence of diseases. The interdisciplinary work, both for evaluation and for determining goals, may be facilitated by the use of a reference classification ${ }^{7}$.

Thus, the ICF has been indicated as a multidimensional tool that allows viewing the human health under various aspects and perform several approaches. It may be used in many sectors, which include health, education, social insurance, occupational medicine, statistics and public policies. Its use should be implemented in various scenarios, such as clinical practice, teaching and research ${ }^{1}$. The acceptance and the use of the ICF as a reference framework and classification have been facilitated by its development and global consensus process, with growing evidence about its validity ${ }^{8}$.

Therefore, this study aimed at investigating the overview of the use of the ICF in Brazil, since its conception in 2001 until the year of 2011, evaluating its usage profile, the dissemination in the academic/scientific field, the principal areas of research and the pattern of national geographic distribution.

\section{Method $: \therefore$.}

This study involves an integrative literature review of national studies related to the ICF. An integrative literature review is a wide methodological approach regarding to reviews that allows the inclusion of diverse types of studies designs, as well allows to reviewing theories and evidence, which provides a complete understanding of the phenomenon analyzed ${ }^{9}$.

To identify the studies the following national databases were consulted: SciELO Brazil (Scientific Electronic Library Online, available at http://www.scielo.br) and Lilacs (LatinAmerican and Caribbean Literature in the Health Sciences, available at http://lilacs.bvsalud.org). A single term was used in both databases: "CIF", as generic term (whereby CIF - Classificação Internacional de Funcionalidade - is the Portuguese language equivalent for ICF).

To complement the search, two international databases were used: PubMed (U.S. National Library of Medicine/National Institutes of Health, available at http://www.ncbi.nlm.nih.gov/ pubmed) and ISI Web of Knowledge, (available at http://apps. isiknowledge.com). However, when using PubMed and ISI, the search terms used were "ICF and Brazil". The searches were conducted in the period between December 15, 2011 and January 20, 2012.

To be included in this study, the article must have been published as scientific article, editorial or technical note. The following types of articles were excluded from the review:

a) all articles that the search retrieved in which the ICF scope was not in the manner expected for this study, that is, it had to be related to the health field: this exclusion criterion is justified as there are publications that have used the ICF and deal with issues of other areas (such as in Agronomy, for example);

b) theses, dissertations were excluded due to the difficulty in fully accessing the material; 
c) studies that were not conducted in Brazil or with the participation of Brazilian institutions, as this study is focused in the national scientific output;

d) duplicated articles.

All the results found were tabulated. Two independent reviewers screened all titles and abstracts of the studies identified in the search. Those that met the inclusion criteria were selected. Then both reviews performed a consensus to decide which study will be included in the review. A third reviewer would be requested to resolve the disagreements in case that both reviewers do not reach a consensual decision. However, it was not necessary. After this stage, the selected studies were read in full-text.

\section{Results $: \because$.}

One hundred and two studies were identified in the first search approach; then, based on the pre-selection criteria, 59 were analyzed, whereby 12 of these were duplicates. At the end, 47 studies were selected and analyzed, as it can be observed in Table 1. It is interesting to note that all results from the ISI database search coincided with the PubMed one, therefore, the duplicates were all excluded. The Lilacs database had the highest number of the retrieved articles. However, it also had the highest number of exclusions.

Appendix 1 presents the titles of 47 studies selected according to the database, its predominant subject, year of publication and institution/institutions linked to it. By segmenting these results according to the health field, the use of the ICF has the following division into Brazilian research: neurology, observed in 16 publications ${ }^{11,16,18,21,23,34,35,38,39,46-51,54}$; orthopaedics, in 12 publications ${ }^{15,19,22,24,25,27,28,30,32,41,42,45}$; health surveillance, in two $^{36,43}$; HIV, in two ${ }^{29,55}$; women's health ${ }^{40}$, endocrinology ${ }^{31}$, hearing and visual deficiencies ${ }^{10}$, gerontology ${ }^{37}$ and public health ${ }^{52}$, in one publication each.

Two publications ${ }^{12,53}$ were included in the review because they were closed related to the health field, however they could be better categorized as ICF's relation with higher education ${ }^{12}$

Table 1. Search results.

\begin{tabular}{lcccc}
\hline Database & $\begin{array}{c}\text { Returned results } \\
\text { retornados }\end{array}$ & $\begin{array}{c}\text { Preselected } \\
\text { articles }\end{array}$ & Duplicates & $\begin{array}{c}\text { Selected } \\
\text { articles }\end{array}$ \\
\hline SciEL0 & 17 & 11 & - & 11 \\
\hline Lilacs & 58 & 33 & $08^{\star}$ & 25 \\
\hline PubMed & 18 & 11 & - & 11 \\
\hline ISI & 09 & 04 & $04^{\star *}$ & 00 \\
\hline Total & 102 & 59 & 12 & 47 \\
\hline
\end{tabular}

*Duplicated over the SciELO; **Duplicated over the PubMed. and urbanization ${ }^{53}$. Further eight publications that have been included were reviews and/or discussions of the ICF itself $1,13,14,17,20,26,33,44$, aiming to provide interpretations and/or perspectives of the ICF utilization, and an additional six studies ${ }^{15,27-29,31,34}$ that have addressed the use or the proposition of the ICF core sets.

The educational institution that has appeared most frequently in national periodical publications was the Universidade de São Paulo (USP), with 11 publications 1,14,18-20,25,28,29,33,41,44, followed by the Universidade Federal de Minas Gerais (UFMG), with seven ${ }^{12,13,15,17,22,30,38}$, and the Universidade Federal da Bahia (UFBA), with three ${ }^{27,32,42}$ and the Universidade Federal do Rio de Janeiro (UFRJ), with two ${ }^{31,34}$. There are another 25 institutions that appear with one publication each ${ }^{10-12,15-18,21,23,24,26,35-40,42,43}$. It is important to note that there are articles that were published by more than one educational institution.

Regarding publications in international periodicals, the most prevalent institution was UFMG, with four publications ${ }^{46,48,51,53}$, followed by the Universidade Federal dos Vales do Jequitinhonha and Mucuri (UFVJM) ${ }^{48}$, Fundação Mineira de Educação e Cultura (FUMEC) ${ }^{49}$, the Universidade de Brasília $(\mathrm{UnB})^{50}$, Worker's Health Reference Center/MG $\mathrm{MG}^{45}$, the Universidade Federal do Ceará (UFC) ${ }^{54}$, the Royal Tropical Institute in Holland ${ }^{52}$, the University of Witwatersrand in South Africa ${ }^{55}$ and the Universidade Federal de São Carlos (UFSCar) ${ }^{47}$, all institution with one publication. Both the Dutch and South African institutions had their research linked to Brazil. Only one editorial ${ }^{13}$ and one technical note ${ }^{44}$ were included in this review. All other studies were original articles.

Annually the Brazilian scientific community shows increasing interest in research on the ICF, as can be seen in Figure 1. The first publication related to the CIF was published in $2003^{20}$, which was the only publication on that year. In 2004, there was another publication ${ }^{21}$. After that, we have the follow trend: two studies in $2005^{1,22}$, two in $2006^{23,52}$, six in $2007^{10,13,24-26,45}$, eight in $2008^{14,27-33}$, nine in $2009^{15-17,34-37,46,53}$, ten in $2010^{11,12,18,38-44}$ and eight in $2011^{19,47-51,54,55}$.

\section{Discussion $\because \therefore$.}

It is evident that the use of the ICF is in the full process of consolidation in addressing human functionality in its entirety, focusing on the possible relationships and interactions between the components that may result in incapacity ${ }^{17}$. Therefore, it was essential to verify how the ICF is used in a country of continental dimensions such as Brazil, with 2,252 public and private higher education institutions, including 


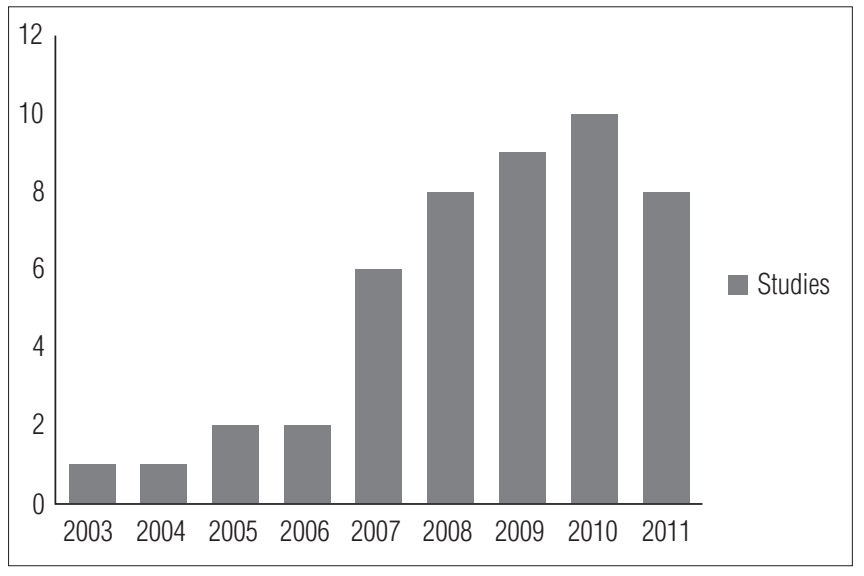

Figure 1. Publication evolution.

universities, university centers and colleges, according to data from $2007^{56}$, and 350 research institutes with approximately 270,000 employees; of these, 77,600 full-time researchers and 48,000 doctors, according to 2005 data $^{57}$.

Our results analysis shows the fact that the majority of research related to the ICF is concentrated in the Brazilian South-East, which coincides with the greater number of educational and research institutions. This finding supports similar studies, such as Bezerra and Neves ${ }^{58}$ studies, which traced the profile of scientific production in occupational health, and the systematic review of Ayres and Silva ${ }^{59}$ on the prevalence of cervical infection by HPV in Brazil.

Several studies have commented about the ICF, however it is necessary to improve the feasibility of its use. For that reason, Røe et al. ${ }^{60}$ commented that the core sets project was developed with the aim to establish a tailored selection of categories to represent the multidisciplinary standard evaluation of specific group of patient, thereby facilitating the comparison of information between countries or regions worldwide ${ }^{61,62}$. Accordingly, the efforts to facilitate the use of the ICF can be supported through the studies with the purpose of establishing shorter and more effective versions of the ICF.

Some authors have developed the proposition and/or utilization of core sets, such as Lima et al. ${ }^{27}$, who developed a core set of the ICF for people with RSI/WRMD, based on an interdisciplinary approach, feasible for application in the treatment and rehabilitation of workers with RSI/WRMD and which could contribute to inserting Brazil in the international discussion dealing with the consequences human illness. Riberto et al. ${ }^{28}$ applied the core set of the ICF for people with chronic pain (CP) and had a not favorable outcome for the validation of this core set, however they highlighted that the characteristics of the sample studied did not allow for their generalization. Andrade et al. ${ }^{34}$ proposed a functionality evaluation model based on a core set of the ICF for individuals with hemiparetic stroke.
As a result, six codes for activities and participation and three codes for environmental factors were used through an association between these categories of the ICF and questions based on analogies of answers to the WHOQOL questionnaire. Buchalla and Cavalheiro ${ }^{29}$ aimed to develop a core set of the ICF for people with AIDS, having defined 40 categories of the ICF as preliminary proposal for this core set. Castro et al. ${ }^{31}$ presented the frequency distribution of the ICF categories of the core set for people with diabetes mellitus, whereby in the studied group of people with diabetes associated with chronic complications, the presence of disability in personal care and environmental barriers suggested that these factors can contribute to a worse quality of life, although impairments in bodily functions and structures have been more prevalent.

It is also important to highlight that most of these studies do not use the ICF as the only "tool", where there are almost always other forms of evaluating the researched variables that are already validated or considered consecrated in the liretature $^{15,34,38,39,45,46}$. Cieza et al. ${ }^{63}$ aimed to establish the relationship between health measures and the ICF and commented how it is important to understand this relationship and also for practical reasons it would be useful if the health status measures could be systematically linked to the corresponding categories of the ICF. The same authors ${ }^{63}$ also informed that the ICF is the base of the linking process and provides a common language for clinical practice, teaching and research. Therefore, it will probably increasingly become the central reference for existing and future measures of health status.

Farin et al. ${ }^{64}$ mentioned that several studies have already demonstrated the interaction through the use of existing evaluation instruments in relation to the coverage of ICF categories, in order to describe the congruency between the ICF and the measurement instruments used in rehabilitation field. However, these relationships are not easy or simple to be established. A clear example is the research of Castaneda and Plácido ${ }^{40}$, who attempted to establish the link between the Kings Health Questionnaire (KHQ) and the ICF. The KHQ was reported by two professionals (individually), followed by discussion and conclusion of codified domains. They found 12 categories of body functions, 22 for activities and participation and 4 for environmental factors. Nevertheless, seven meaningful concepts of the questionnaire could not be linked to the ICF.

Silva Drummond et al. ${ }^{45}$ used similar methodology when investigating the relation between the Disabilities of Arm, Shoulder and Hand (DASH) and the ICF, observed that the structural components of the body and environmental factors of the ICF are not considered by the DASH, requiring the use of other instruments simultaneously to contemplate the evaluation of such components. 
Two multicentric studies were found, being the first developed by van Brakel et al. ${ }^{52}$, with the participation of Brazil, India and Nepal, aiming to develop a scale based upon the ICF domains to measure participation to be used in rehabilitation, stigma reduction and social integration programs. The authors concluded that the scale was valid and reliable to measure participation of individuals with leprosy or deficiency, and is expected to be valid in other conditions (stigmatized), but without confirmation. They also reported that the scale allowed for the collection of participation data and evaluation of the treatment impact to improve social participation. Another study, developed by Myezwa et al. ${ }^{55}$, indicated four studies (three South-African and one Brazilian), which used the ICF to describe how HIV affects the functioning and health of people in different environmental contexts, having concluded that the ICF provided a useful framework to describe the functioning of people with HIV and the impact on the environment.

However, the use of the ICF does not fit all scenarios. Accordingly, Kjellberget al. ${ }^{65}$ evaluated patients in a hospital environment using the CIF aiming to investigate its clinical relevance and its potential implementation. They identified that the clinical relevance was considered low, its potential for application and patient centered approach was classified as weak, in addition of the target group not have not benefitted from the use of the ICF.

Sabino et al..$^{30}$ analyzed the difficulties encountered in the use of the ICF to codify activities/participation of patients with musculoskeletal problems in the lower limbs and the lumbar region, where the ICF allowed the characterization of functionality of individuals, but presented some issues that should be considered for its improvement, such as the multiplicity of codes for one same condition or the presence of inaccurate and/or wide ranging codes. The authors also suggested that the use of the ICF in clinical and research practice would contribute to newer versions of the ICF in order to make it more practical and precise, a fact that has already occurred, for example, with the International Classification of Diseases (ICD).

The majority of studies on the ICF discuss the motor disability. Torres et al. ${ }^{10}$ applied ICF concepts to people with auditory or visual deficiency to explain some of the existing differences regarding access to information and communication among those people who, although presenting similar impairment, experience different levels of disability. Results evidenced large variability between people with one same type of sensorial deficiency and highlighted some of the mistakes and losses that can occur when this diversity is not considered. These results considered the degree of difficulty manifested by a specific individual, that is, particular to him/her and associated with the disability he/she experiences (and not the deficiency that this person may have). For example, it is known that blind people do not perceive visual information, but this is not enough to know if they can read or write. Apart from this, it is known that deaf people do not comprehend sound information, however it cannot be inferred if they know how to speak a foreign language.

In another study that diverges from the conventional patterns of ICF use, Andrade ${ }^{12}$ sought to relate the skills and abilities set out in the National Curriculum Guidelines for Under-Graduate courses in Physical Therapy (DCN/FISIO) with the biopsychosocial proposal of the ICF, having found that the result of the link between the ICF and the DCN/FISIO offered grounds to orient the evaluation content according to requirements from the educational ministery and the biopsychosocial approach set out by the WHO.

Still in the educational field, Silva et al. ${ }^{32}$ discussed the characteristics of physical therapy training in the light of the functionality application and adoption process in the rehabilitation of orthopaedic patients, obtaining information from 93 patient records based on a form containing predefined ICF categories. Results show that physical therapy undergraduates are focusing their attention on bodily functions and structures preferentially, following a biomedical type of training. The lack of information on other components of functionality indicates that there is still a gap between the concepts of more modern functionality and physical therapy training in the orthopaedic field.

Ferreira et al. ${ }^{53}$ used a theoretical model of the ICF to verify the functional state of the elderly living in the metropolitan area of Belo Horizonte. They found an impairment prevalence of $47.1 \%$. They also reported that $84 \%$ of the elderly were satisfied with their neighborhood, but only $18.4 \%$ trusted the people around them, while $78 \%$ said they were afraid of being assaulted and $48.2 \%$ were afraid of falling due to defective sidewalks. As such, the authors concluded that urban infrastructure interventions, such as improvements in public sidewalks or greater security, can influence the frequency of the elderly walking in their neighborhoods.

With regards to the databases, the observation that all the ISI results coincided with the PubMed database may possibly be explained due to the journals that are part of one of these databases having a very high impact factor resulting in the other search engine also indexing it. Besides this, PubMed, as a specifically health area index, ended up returning more results than ISI, which has a more generalized scope. Lilacs was the one that had the largest number of returns. However, it also had the largest number of ineligible studies, which may be explained by the fact that Lilacs indexes material other than articles, such as theses and dissertations. 
When comparing this review and studies with similar purposes, we only found the publication by Comín Comín et al. ${ }^{66}$, who analyzed scientific-professional production according to the ICF model between 2001 and 2011 in Spain, comparing it to other geographically close European countries. That study observed similar results compared to ours, as they reported the occurrence of 88 studies, of which, after the exclusion criteria, resulted in 47 studies included in the review, coincidentally the same number presented in this study. Therefore, it may be considered that Brazilian scientific output is similar to its Spanish counterpart in dealing with national works on the ICF.

Despite the important contributions of the study in so far as it refers to the evolution of ICF use, it is important to mention, with limitations, the editorial trend of publishing favorable results or publication bias, which can compromise, in part, the results presented, or moreover, the possibility of other important results not having been validated as a result of studies performed that were not published in indexed research databases.

\section{Conclusions $\because \because$.}

Based on the review cut-off, it is possible to confirm that the use of the ICF is still incipient in the Brazilian scientific community, despite the growing interest in its use. The potential for ICF growth is compatible with the demand for knowledge generated by it, both in the public and private sectors, involving the relations between health, functionality and environment, principally in so far as it refers to indicators of health and measures alternative to the traditional morbidity and mortality rates.

From the point of view of areas of use, we noted a concentration of studies in the areas related to the locomotor system and, in relation to spatial distribution, we identified that a majority of studies were carried out in the South-East region.

Finally, with the aim of improving and widening the use of this important classification, the authors suggest the adoption of simple measures, such as the training of professionals and academics and the implementation of ICF code use in public health systems.

\section{References: ::}

1. Farias N, Buchalla CM. A classificação internacional de funcionalidade, incapacidade e saúde da organização mundial da saúde: conceitos, usos e perspectivas. Rev Bras Epidemiol. 2005;8(2):187-93.

2. Organização Mundial de Saúde (OMS). Organização Panamericana de Saúde (OPAS). CIF classificação internacional de funcionalidade, incapacidade e saúde. Universidade de São Paulo. São Paulo: Edusp; 2008.

3. Organização Mundial de Saúde. Rumo a uma linguagem comum para funcionalidade, incapacidade e saúde: CIF. Genebra: OMS/WHO; 2002

4. Nordenfelt L. Action theory, disability and ICF. Disabil Rehabil. 2003;25(18):1075-9

5. Brockow T, Cieza A, Kuhlow H, Sigl T, Franke T, Harder M, et al. Identifying the concepts contained in outcome measures of clinical trials on musculoskeletal disorders and chronic widespread pain using the international classification of functioning, disability and health as a reference. J Rehabil Med. 2004;(44 Suppl):30-6

6. Santana E. A classificação internacional de funcionalidade, incapacidade e saúde (CIF) em fisioterapia: uma revisão bibliográfica [Dissertação]. Universidade de São Paulo; 2008.

7. Finger ME, Cieza A, Stoll J, Stucki G, Huber EO. Identification of intervention categories for physical therapy, based on the international classification of functioning, disability and health: a Delphi exercise. Phys Ther. 2006;86(9):1203-20.

8. Cieza A, Stucki G. The international classification of functioning disability and health: its development process and content validity. Eur J Phys Rehabil Med. 2008;44(3):303-13.

9. Whittemore R, Knafl K. The integrative review: update methodology. J Adv Nurs. 2005;52(5):546-53

10. Torres EF, Mazzoni AA, Mello AG. Nem toda pessoa cega lê em Braille nem toda pessoa surda se comunica em língua de sinais. Educ Pesqui. 2007:33(2):369-85.

11. Machado WCA, Scramin AP. (In)dependência funcional na dependente relação de homens tetraplégicos com seus (in)substituíveis pais/cuidadores. Rev Esc Enferm USP. 2010;44(1):53-60.

12. Andrade PMO. Avaliação do estágio da fisioterapia conforme as diretrizes curriculares e a perspectiva biopsicossocial da organização mundial de saúde. Avaliação (Campinas). 2010;15(2):121-34

13. Sampaio RF, Mancini MC. Weaving a Net of ICF Users. Rev Bras Fisioter. 2007;11(4):V-vi. DOI:10.1590/S1413-35552007000400001.

14. Di Nubila HBV, Buchalla CM. 0 papel das Classificações da OMS - CID e CIF nas definições de deficiência e incapacidade. Rev Bras Epidemiol. 2008:11(2):324-35.
15. Ocarino JM, Gonçalves GGP, Vaz DV, Cabral AAV, Porto JV, Silva MT. Correlation between a functional performance questionnaire and physical capability tests among patients with low back pain. Rev Bras Fisioter. 2009;13(4):343-9. D0I:10.1590/S1413-35552009005000046.

16. Brasileiro IC, Moreira TMM, Jorge MSB, Queiroz MVO, Mont'Alverne DGB. Atividades e participação de crianças com paralisia cerebral conforme a Classificação Internacional de Funcionalidade, Incapacidade e Saúde. Rev Bras Enferm. 2009;62(4):503-11.

17. Sampaio RF, Luz MT. Funcionalidade e incapacidade humana: explorando o escopo da classificação internacional da Organização Mundial da Saúde. Cad Saúde Pública. 2009;25(3):475-83

18. Siqueira IM, Santana CS. Propostas de acessibilidade para a inclusão de pessoas com deficiências no ensino superior. Rev Bras Educ Espec. 2010;16(1):127-36.

19. Riberto M, Chiappetta LM, Lopes KAT, Battistella LR. A experiência brasileira com o core set da classificação internacional de funcionalidade, incapacidade e saúde para Iombalgia. Coluna/ Columna. 2011;10(2):121-6

20. Buchalla CM. A Classificação Internacional de Funcionalidade, Incapacidade e Saúde. Acta Fisiátrica. 2003;10(1):29-31.

21. Silva OMP, Panhoca L, Blanchman IT. Os pacientes portadores de necessidades especiais: revisando os conceitos de incapacidade, deficiência e desvantagem. Salusvita. 2004;23(1):109-16.

22. Sampaio RF, Mancini MC, Goncalves GGP, Bittencourt NFN, Miranda AD, Fonseca ST. Aplicação da classificação internacional de funcionalidade, incapacidade e saúde (CIF) na prática clínica do fisioterapeuta. Rev Bras Fisioter. 2005;9(2):129-36.

23. Silva KJ, Silva CS. Fatores ambientais como modificadores de mobilidade e função da criança com deficiência física. Temas Desenvolv. 2006;15(87/88):47-51.

24. César CM, Alves FC, Gonsálves LTN, Ocarino J, Lanna P. Avaliação da progressão no desempenho e capacidade funcional em indivíduos em reabilitação devido à síndrome patelo femoral. Fisioter Bras. 2007;8(1):19-24

25. De Carlo MMRP, Elui VMC, Scarpelini S, Alves ALA, Salim FM, Santana CS. Trauma, reabilitação e qualidade de vida. Medicina (Ribeirão Preto). 2007;40(3):335-44.

26. Diniz D, Medeiros M, Squinca F. Reflexões sobre a versão em Português da Classificação Internacional de Funcionalidade, Incapacidade e Saúde. Cad Saúde Pública. 2007;23(10):2507-10. 
27. Lima MAG, Neves RF, Tironi MOS, Nascimento AMDN, Magalhães FB. Avaliação da funcionalidade dos trabalhadores com LER/DORT: a construção do core set da CIF para LER/ DORT. Acta Fisiátrica. 2008;15(4):229-35.

28. Riberto M, Saron TRP, Battistella LR. Resultados do core set da CIF de dor crônica generalizada em mulheres com fibromialgia no Brasil. Acta Fisiátrica. 2008;15(1):6-12.

29. Buchalla CM, Cavalheiro TR. A Classificação Internacional de Funcionalidade, Incapacidade e Saúde e a Aids: uma proposta de core set. Acta Fisiátrica. 2008;15(1):42-8.

30. Sabino GS, Coelho CM, Sampaio RF. Utilização da Classificação Internacional de Funcionalidade, Incapacidade e Saúde na avaliação fisioterapêutica de indivíduos com problemas musculoesqueléticos nos membros inferiores e região lombar. Acta Fisiátrica. 2008:15(1):24-30.

31. Castro CLN, Braulio VB, Dantas FAL, Couto APCB. Qualidade de vida em diabetes mellitus e Classificação Internacional de Funcionalidade, Incapacidade e Saúde: estudo de alguns aspectos. Acta Fisiátrica. 2008;15(1):13-7.

32. Silva ACL, Neves RF, Riberto M. A formação fisioterapêutica no campo da ortopedia: uma visão crítica sob a óptica da funcionalidade. Acta Fisiátrica. 2008;15(1):18-23.

33. Mângia EF, Muramoto MT, Lancman S. Classificação Internacional de Funcionalidade e Incapacidade e Saúde (CIF): processo de elaboração e debate sobre a questão da incapacidade. Rev Ter Ocup. 2008:19(2):121-30.

34. Andrade FG, Castaneda L, Martins JV. Modelo de avaliação para indivíduos hemiparéticos baseado no core set abreviado da classificação internacional de funcionalidade (CIF) para acidente vascular encefálico. Ter Man. 2009;7(32):278-82.

35. Brasileiro IC, Moreira TMM, Jorge MSB. Interveniência dos fatores ambientais na vida de crianças com paralisia cerebral. Acta Fisiátrica. 2009;16(3):132-7.

36. Maeno M, Takahashi MAC, Lima MAG. Reabilitação profissional como política de inclusão social. Acta Fisiátrica. 2009;16(2):53-8.

37. Depolito C, Leocadio PLLF, Cordeiro RC. Declínio funcional de idosa institucionalizada: aplicabilidade do modelo da Classificação Internacional de Funcionalidade, Incapacidade e Saúde. Fisioter Pesqui. 2009;16(2):183-9.

38. Faria CDCM, Saliba VA, Teixeira-Salmela LF, Nadeau S. Comparação entre indivíduos hemiparéticos com e sem histórico de quedas com base nos componentes da Classificação Internacional de Funcionalidade, Incapacidade e Saúde. Fisioter Pesqui. 2010;17(3):242-7.

39. Nickel R, Pinto LM, Lima AP, Navarro EJ, Teive HAG, Becker N, et al. Estudo descritivo do desempenho ocupacional do sujeito com doença de Parkinson: 0 uso da CIF como ferramenta para classificação da atividade e participação. Acta Fisiátrica. 2010;17(1):13-7.

40. Castaneda L, Plácido T. Ligação do King 's Health Questionário com a Classificação Internacional de Funcionalidade, Incapacidade e Saúde, para avaliação de pacientes com incontinência urinária pós cirurgia oncológica ginecológica. Acta Fisiátrica. 2010;17(1):18-21.

41. Toldrá RC, Daldon MTB, Santos MC, Lancman S. Facilitadores e barreiras para o retorno ao trabalho: a experiência de trabalhadores atendidos em um centro de referência em saúde do trabalhador SP, Brasil. Rev Bras Saúde Ocup. 2010;35(121):10-22.

42. Lima MAG, Andrade AGM, Bulcão CMA, Mota EMCL, Magalhães FB, Carvalho RCP, et al. Programa de reabilitação de trabalhadores com LER/DORT do Cesat/Bahia: ativador de mudanças na saúde do trabalhador. Rev Bras Saúde Ocup. 2010;35(121):112-21.

43. Simonelli AP, Camarotto JA, Bravo ES, Vilela RAG. Proposta de articulação entre abordagens metodológicas para melhoria do processo de reabilitação profissional. Rev Bras Saúde Ocup. 2010;35(121):64-73.

44. Di Nubila HBV. Uma introdução à CIF - Classificação Internacional de Funcionalidade, Incapacidade e Saúde. Rev Bras Saúde Ocup. 2010;35(121):122-3.

45. Silva Drummond A, Ferreira Sampaio R, Cotta Mancini M, Noce Kirkwood R, Stamm TA. Linking the disabilities of arm, shoulder, and hand to the International Classification of Functioning, Disability, and Health. J Hand Ther. 2007;20(4):336-43.
46. Teixeira-Salmela LF, Neto MG, Magalhães LC, Lima RC, Faria CD. Content comparisons of stroke-specific quality of life based upon the international classification of functioning, disability, and health. Qual Life Res. 2009;18(6):765-73.

47. Santos AN, Pavão SL, de Campos AC, Rocha NACF. International classification of functioning disability and health in children with cerebral palsy. Disabil Rehabil. 2012;34(12):1053-8.

48. Oliveira Andrade PM, Oliveira Ferreira F, Haase VG. Multidisciplinary perspective for cerebral palsy assessment after an International, Classification of Functioning, Disability and Health training. Dev Neurorehabil. 2011;14(4):199-207.

49. Faria-Fortini I, Michaelsen SM, Cassiano JG, Teixeira-Salmela LF. Upper extremity function in stroke subjects: relationships between the international classification of functioning, disability and health domains. J Hand Ther. 2011;24(3):257-64

50. Martins EF, De Sousa PH, Barbosa PH, De Menezes LT, Costa AS. A Brazilian experience to describe functioning and disability profiles provided by combined use of ICD and ICF in chronic stroke patients at home-care. Disabil Rehabil. 2011;33(21-22):2064-74.

51. Magalhães LC, Cardoso AA, Missiuna C. Activities and participation in children with developmental coordination disorder: a systematic review. Res Dev Disabil. 2011;32(4):1309-16

52. van Brakel WH, Anderson AM, Mutatkar RK, Bakirtzief Z, Nicholls PG, Raju MS, et al. The participation scale: measuring a key concept in public health. Disabil Rehabil. 2006;28(4):193-203.

53. Ferreira FR, César CC, Camargos VP, Lima-Costa MF, Proietti FA. Aging and urbanization: the neighborhood perception and functional performance of elderly persons in Belo Horizonte Metropolitan Area-Brazil. J Urban Health. 2010;87(1):54-66.

54. Vall J, Costa CMC, Pereira LF, Friesen TT. Application of International Classification of Functioning Disability and Health (ICF) in individuals with spinal cord injury. Arq Neuropsiquiatr. 2011;69(3):513-8.

55. Myezwa H, Buchalla CM, Jelsma J, Stewart A. HIV/AIDS: use of the ICF in Brazil and South Africa - comparative data from four cross-sectional studies. Physiotherapy. 2011;97(1):17-25.

56. INEP (Instituto Nacional de Estudos e Pesquisas Educacionais Anísio Teixeira). Censo da educação superior. Brasília, DF; 2008.

57. Ministério da Ciência e Tecnologia. Brasil. Plano de Ação 2007-2010. Brasília, DF; 2010.

58. Bezerra MLS, Neves EB. Perfil da produção científica em saúde do trabalhador. Saúde Soc 2010;19(2):384-94

59. Ayres ARG, Silva GA. Prevalência de infecção do colo do útero pelo HPV no Brasil: revisão sistemática. Rev Saúde Pública. 2010:44(5):963-74

60. Røe C, Sveen U, Geyh S, Cieza A, Bautz-Holter E. Construct dimensionality and properties of the categories in the ICF core set for low back pain. J Rehabil Med. 2009;41(6):429-37.

61. Stucki G, Kostanjsek N, Ustün B, Cieza A. ICF-based classification and measurement of functioning. Eur J Phys Rehabil Med. 2008:44(3):315-28.

62. Grill E, Stucki G. Scales could be developed based on simple clinical ratings of international classification of functioning, disability and health core set categories. J Clin Epidemiol. 2009;62(9):891-8.

63. Cieza A, Brockow T, Ewert T, Amman E, Kollerits B, Chatterji S, et al. Linking health-status measurements to the international classification of functioning, disability and health. J Rehabi Med. 2002;34(5):205-10.

64. Farin E, Fleitz A, Frey C. Psychometric properties of an international classification of functioning disability and health (ICF)-oriented, adaptive questionnaire for the assessment of mobility, selfcare and domestic life. J Rehabil Med. 2007;39(7):537-46.

65. Kjellberg A, Bolic V, Haglund L. Utilization of an ICF-based assessment from occupationa therapists' perspectives. Scand J Occup Ther. 2012;19(3):274-81.

66. Comín Comín M, Ruiz Garrós C. Franco E, Damian J, Ruiz Tovar M, de Pedro-Cuesta J, et al. Scientific-professional production on the ICF disability model in Spain. A literature review (2001-2010). Gac Sanit. 2011;25 Suppl 2:39-46. 
Appendix 1. Selected studies.

\begin{tabular}{|c|c|c|c|c|}
\hline Database & Title & Theme & Year & Institution \\
\hline SciELO & Not every blind person reads Braille and not every deaf person knows sign language ${ }^{10}$. & $\begin{array}{l}\text { Visual or } \\
\text { hearing impairments }\end{array}$ & 2007 & UFSC \\
\hline SciELO & $\begin{array}{l}\text { Functional (in)dependence in the dependent relationship of quadriplegic men with their (un) } \\
\text { replaceable parents/caregivers }{ }^{11}\end{array}$ & Neurology & 2010 & UEM \\
\hline SciELO & $\begin{array}{l}\text { Evaluation of curriculum guidelines according to the biopsychosocial perspective of the world } \\
\text { health organization }(\mathrm{WHO})^{12} \text {. }\end{array}$ & Education & 2010 & $\begin{array}{l}\text { UFMG } \\
\text { UFVJM }\end{array}$ \\
\hline SciELO/Lilacs & The role of WHO Classifications - ICD and ICF - on definitions of disability ${ }^{14}$. & ICF review & 2008 & USP \\
\hline SciELO/ Lilacs & $\begin{array}{l}\text { Correlation between a functional performance questionnaire and physical capability tests } \\
\text { among patients with low back pain }{ }^{15} \text {. }\end{array}$ & Orthopaedics & 2009 & $\begin{array}{l}\text { UNIBH } \\
\text { UFMG }\end{array}$ \\
\hline SciELO/Lilacs & $\begin{array}{l}\text { Activities and participation of children with Cerebral Palsy according to the International Clas- } \\
\text { sification of Functioning, Disability and Health'16. }\end{array}$ & Neurology & 2009 & UNIFOR \\
\hline SciELO/ Lilacs & $\begin{array}{l}\text { The Brazilian experience with the international classification of functioning, disability and } \\
\text { health core set for low back pain }{ }^{19} \text {. }\end{array}$ & Orthopaedics & 2011 & USP \\
\hline Lilacs & The International Classification of Functioning, Disability and Health ${ }^{20}$. & ICF review & 2003 & USP \\
\hline Lilacs & Reviewing the concepts of disability, impairment and handicap ${ }^{21}$. & Neurology & 2004 & USC \\
\hline Lilacs & $\begin{array}{l}\text { Application of the international classification of functioning, disability and health (ICF) in } \\
\text { physical therapists }{ }^{\prime} \text { clinical practice }{ }^{22} \text {. }\end{array}$ & Orthopaedics & 2005 & UFMG \\
\hline Lilacs & Environmental factors modifying mobility and function to the handicapped child²3. & Neurology & 2006 & UNAERP \\
\hline Lilacs & $\begin{array}{l}\text { Improvement evaluation in functional performance and capacity in individual rehabilitation due } \\
\text { to patellofemoral syndrome }{ }^{24} \text {. }\end{array}$ & Orthopaedics & 2007 & UNIBH \\
\hline Lilacs & Trauma, rehabilitation and quality of life ${ }^{25}$. & Orthopaedics & 2007 & USP \\
\hline Lilacs & $\begin{array}{l}\text { The use of the International Classification of Functioning, Disability and Health in the physical } \\
\text { therapy assessment of individuals with musculoskeletal disorders of the lower limbs and } \\
\text { lumbar region }{ }^{30} \text {. }\end{array}$ & Orthopaedics & 2008 & UFMG \\
\hline Lilacs & $\begin{array}{l}\text { Quality of life in diabetes mellitus and the International Classification of Functioning, Dis- } \\
\text { ability and Health - a study of some aspects }{ }^{31} \text {. }\end{array}$ & Endocrinology & 2008 & UFRJ \\
\hline Lilacs & $\begin{array}{l}\text { The physical therapy background in the field of the orthopedics: a critical view under the } \\
\text { optics of functioning }{ }^{32} \text {. }\end{array}$ & Orthopaedics & 2008 & UFBA \\
\hline Lilacs & $\begin{array}{l}\text { The International Classification of Functioning, Disability and Health (ICF): elaboration } \\
\text { process and debate about the disability question }{ }^{33} \text {. }\end{array}$ & ICF review & 2008 & USP \\
\hline Lilacs & $\begin{array}{l}\text { Evaluation model for hemiparetic individuals based on brief core set for stroke of International } \\
\text { Classification of Functioning (ICF) })^{34} \text {. }\end{array}$ & Neurology & 2009 & UFRJ \\
\hline Lilacs & Intervention of environmental factors in the life of children with cerebral palsy ${ }^{35}$. & Neurology & 2009 & UECE \\
\hline Lilacs & Occupational rehabilitation as a social inclusion policy ${ }^{36}$. & Health surveillance & 2009 & $\begin{array}{l}\text { Fundação } \\
\text { Jorge Duprat } \\
\text { Figueiredo }\end{array}$ \\
\hline Lilacs & $\begin{array}{l}\text { Functional decline of an institutionalized elderly woman: applicability of the model of the } \\
\text { International Classification of Functioning, Disability and Health }{ }^{37} \text {. }\end{array}$ & Gerontology & 2009 & UNIFESP \\
\hline Lilacs & $\begin{array}{l}\text { Comparison between post-stroke hemiparetic subjects with and without history of falls on the } \\
\text { basis of the International Classification of Functioning, Disability and Health }{ }^{38} \text {. }\end{array}$ & Neurology & 2010 & $\begin{array}{l}\text { UFMG/ } \\
\text { Université de } \\
\text { Montréal, } \\
\text { Canadá }\end{array}$ \\
\hline
\end{tabular}


Appendix 1. Continue.

\begin{tabular}{|c|c|c|c|c|}
\hline Lilacs & $\begin{array}{l}\text { Descriptive study of occupational performance of subjects with Parkinson's disease: the use of } \\
\text { ICF as a tool for the classification of activity and participation }{ }^{39} \text {. }\end{array}$ & Neurology & 2010 & UFPR \\
\hline Lilacs & $\begin{array}{l}\text { Link between the King's Health Questionnaire and the International Classification of Function- } \\
\text { ing, Disability and Health, for the evaluation of patients with urinary incontinence after gyneco- } \\
\text { logical oncology surgery }{ }^{40} \text {. }\end{array}$ & Women's health & 2010 & $\begin{array}{l}\text { UNICID } \\
\text { IN Câncer }\end{array}$ \\
\hline Lilacs & $\begin{array}{l}\text { Facilitating factors and barriers for returning to work - the experience of workers treated at a } \\
\text { Workers' Health Reference Center in São Paulo, Brazil| }{ }^{41} \text {. }\end{array}$ & Orthopaedics & 2010 & USP \\
\hline Lilacs & $\begin{array}{l}\text { Cesat/Bahia rehabilitation program for workers with RSI/WRMD - a starter for changes in } \\
\text { Workers' Health }{ }^{42} \text {. }\end{array}$ & Orthopaedics & 2010 & $\begin{array}{l}\text { UFBA } \\
\text { CESAT/BA } \\
\text { UFPB }\end{array}$ \\
\hline Lilacs & $\begin{array}{l}\text { Proposing an articulation between methodologies to improve occupational rehabilita- } \\
\text { tion process }{ }^{43} \text {. }\end{array}$ & Health surveillance & 2010 & UFSCar \\
\hline Lilacs & An introduction to the International Classification of Functioning, Disability and Health ${ }^{44}$ & ICF review & 2010 & USP \\
\hline PubMed & $\begin{array}{l}\text { Linking the disabilities of arm, shoulder, and hand to the International Classification of Func- } \\
\text { tioning, Disability and Health }{ }^{45} \text {. }\end{array}$ & Orthopaedics & 2007 & $\begin{array}{l}\text { Worker's } \\
\text { Health Refer- } \\
\text { ence Center/ } \\
\text { MG }\end{array}$ \\
\hline PubMed & $\begin{array}{l}\text { Content comparisons of stroke-specific quality of life based upon the International Classifica- } \\
\text { tion of Functioning, Disability and Health }{ }^{46} \text {. }\end{array}$ & Neurology & 2009 & UFMG \\
\hline PubMed & $\begin{array}{l}\text { International classification of functioning, disability and health in children with cer- } \\
\text { ebral palsy }{ }^{47} \text {. }\end{array}$ & Neurology & 2011 & UFSCar \\
\hline PubMed & $\begin{array}{l}\text { Multidisciplinary perspective for cerebral palsy assessment after an International, Classifica- } \\
\text { tion of Functioning, Disability and Health training }{ }^{48} \text {. }\end{array}$ & Neurology & 2011 & $\begin{array}{l}\text { UFMG/ } \\
\text { UFVJM }\end{array}$ \\
\hline PubMed & $\begin{array}{l}\text { Upper extremity function in stroke subjects: relationships between the International Classifica- } \\
\text { tion of Functioning, Disability, and Health domains }{ }^{49} \text {. }\end{array}$ & Neurology & 2011 & FUMEC \\
\hline PubMed & $\begin{array}{l}\text { A Brazilian experience to describe functioning and disability profiles provided by combined } \\
\text { use of ICD and ICF in chronic stroke patients at home-care }{ }^{50} \text {. }\end{array}$ & Neurology & 2011 & UnB \\
\hline PubMed & Activities and participation in children with developmental coordination disorder: A systematic review ${ }^{51}$. & Neurology & 2011 & UFMG \\
\hline PubMed/ISI & The participation scale: measuring a key concept in public health ${ }^{52}$. & Public health & 2006 & $\begin{array}{l}\text { Royal Tropical } \\
\text { Institute }\end{array}$ \\
\hline PubMed/ISI & $\begin{array}{l}\text { Aging and urbanization: the neighborhood perception and functional performance of elderly } \\
\text { persons in Belo Horizonte Metropolitan Area-Brazil53. }\end{array}$ & Urbanization & 2009 & UFMG \\
\hline PubMed/ISI & $\begin{array}{l}\text { Application of International Classification of Functioning, Disability and Health (ICF) in } \\
\text { individuals with spinal cord injury }{ }^{54} \text {. }\end{array}$ & Neurology & 2011 & UFC \\
\hline PubMed/ISI & $\begin{array}{l}\text { HIV/AIDS: use of the ICF in Brazil and South Africa - comparative data from four cross- } \\
\text { sectional studies }{ }^{55} \text {. }\end{array}$ & HIV & 2011 & $\begin{array}{l}\text { University of } \\
\text { Witwatersrand }\end{array}$ \\
\hline
\end{tabular}

